\title{
Imigran dan Warga Keturunan Jepang di Amerika Serikat: Sentimen-Sentimen Terhadapnya Dulu dan Kini
}

\author{
Rifka Pratama \\ Program Studi S1 Sastra Inggris (Bidang Pengkajian Amerika) \\ Fakultas Ilmu Budaya, Universitas Diponegoro \\ pratamarifka@live.undip.ac.id
}

\begin{abstract}
Abstrak
Sejarah mencatat sentimen rasial yang tertuang dalam produk undang-undang Amerika Serikat seperti Chinese Exclusion Act 1882, pada masanya turut menyasar para imigran dan warga keturunan Jepang. Beragam tindakan kekerasan verbal maupun fisik dan diskriminasi dialami imigran Asia, dalam konteks ini Cina dan Jepang, ketika itu. Lebih lanjut, merebaknya Covid-19 dalam kurun dua tahun ini kembali memunculkan masalah sosial serupa bagi komunitas imigran dan warga keturunan Asia, termasuk Jepang. Isu berhembus memojokan para pendatang dan warga keturunan Asia sebagai tertuduh pembawa virus Covid-19. Dengan demikian, aksi-aksi rasis, diskriminatif, dan xenophobic terrekam pada dua konteks waktu yang berbeda. Dengan mengumpulkan data-data melalui metode studi pustaka dan kemudian mengolahnya, diketahui terdapat perbedaan dan kesamaan fenomena di tengah sentimensentimen yang menarget imigran maupun warga keturunan Jepang di Amerika. Perbedaan yang dimaksud merujuk pada aspek pemicu. Pada masa-masa awal kedatangannya, sentimen terhadap imigran Jepang di Amerika Serikat dipicu oleh masalah kesempatan kerja dan kecurigaan bernuansa politik. Sementara itu, pada kurun waktu pandemi Covid-19 sentimen anti-Asian dipicu oleh isu penyebaran virus Covid-19. Di sisi lain, terdapat kesamaan dalam munculnya sentimen-setimen anti-Asian dulu dan kini yaitu tersebarnya informasi palsu dan provokatif, merebaknya prasangka dan diskriminasi rasial, adanya peran tokoh publik dalammenyebarkan kebencian, dan adanya kebijakan hukum yang diambil oleh otoritas untuk merespon isu terkait.
\end{abstract}

Kata Kunci: Amerika Serikat, Jepang, Imigran, Xenophobia, Covid-19

\begin{abstract}
Chinese Exclusion Act of 1882, which was one of the US Federal Laws restricting immigration, was meant to target Chinese immigrants at that time. Being among the Asian communities in the US, the Japanese immigrants were unsurprisingly affected. Racial discrimination and hatred began to arise as the implementation of the law was going on. Various acts of verbal and physical violence suffered by the Asian (Chinese and Japanese) immigrants at that time. Further, the outbreak of Covid-19 in the past two years has raised similar social problems for the immigrant communities and people of Asian descent including Japanese. The issue of cornering the immigrants and the residents of this descent as being accused of carrying the Covid-19 virus arises. Various acts of hatred begin to target the immigrants and citizens of Asian descent. Applying the library research method and processing the relevant data, there found differences and similarities amidst the sentiments targeting the immigrants and citizens of Japanese descent in America. The difference refers to the triggering aspect. In the early days of their arrival, the anti-Japanese immigrant sentiment in the United States was more motivated by the problems of job opportunity and political suspicions. Meanwhile, during the Covid-19 pandemic anti-Asian sentiment was triggered by the issue of the spread of the Covid-19 virus. On the other hand, there are similarities to the emergence of anti-Asian sentiments today including the spread offalse and provocative information, the spread of racial prejudice and discrimination, the role of public figures in spreading hatred, and the existence of legal policies taken by authorities to respond to the related issues.
\end{abstract}

Keywords: United States, Japanese, Immigrants, Xenophobia, Covid-19

\section{Pendahuluan}

Kelompok imigran Asia mengisi porsi cukup besar dalam sebaran populasi imigran di Amerika Serikat. Mengacu pada Biro Sensus Amerika dan American Community Survey pada tahun 2019 terdapat 14,1 juta imigran Asia di Amerika Serikat (Migration Policy Institute, 2021). Masih mengacu sumber yang sama, jumlah ini merupakan peningkatan 29 kali lipat dari populasi kelompok imigran Asia 
di Amerika Serikat pada tahun 1960. Dalam statistik populasi tersebut Jepang mengisi porsi 333.000 jiwa atau 2,4\% dari total populasi imigran Asia Timur di Amerika Serikat. Jumlah ini menunjukan bahwa Jepang merupakan urutan ke-4 dalam klasifikasi imigran yang berasal dari Asia Timur. Penyumbang imigran terbesar dalam klasifikasi geografis Asia Timur adalah Cina (mengecualikan Taiwan) (Migration Policy Institute, 2021). Pada tahun 2015, Honolulu, Los Angeles, dan San Fransisco merupakan 3 besar wilayah dengan populasi warga keturunan Jepang (Pew Research Center, 2017).

Alih-alih menghubungkan imigrasi bangsa Jepang ke Amerika dengan masalah politik ataupun peperangan dua negara tersebut, sejarah mencatat bahwa ekonomi menjadi faktor pendorong dan penarik terjadinya imigrasi awal. Beberapa sumber menyebut imigrasi bangsa Jepang ke Amerika dimulai pada kurun 1860an. Sumber lain menyebut telah terjadi imigrasi pada 1800an (Ichise, 2005). Para imigran Jepang awal ini tersebar dalam beberapa sektor industri di Amerika diantaranya perkebunan tebu di Hawaii, pertambangan, pembangunan rel kereta api, dan penebangan kayu. Ichise (2005) menyebut pelayaran Scioto pada 17 Mei 1868 menunjukan 153 imigran datang dari Yokohama untuk kemudian bekerja pada perkebunan tebu di Hawaii. Jumlah imigran ini tergolong besar pada masanya.

Terdapat beragam faktor yang mendorong adanya imigrasi bangsa Jepang ke Amerika. Jones (2005) menyatakan setelah 250 tahun penerapan sakoku (aturan ketat larangan keluar - masuk Jepang), kekaisaran Meiji melakukan restorasi yang memungkinkan terbukanya kran emigrasi. Perubahan tatanan dan arah pemerintahan di Jepang kala itu membutuhkan pembiayaan tinggi. Hal ini kemudian mengakibatkan beban pajak yang tinggi kepada rakyat (kelas petani) dan tidak jarang banyak diantaranya kehilangan tanah garapan (Jones, 2005). Kala itu, kemiskinan mengancam. Sakoku secara resmi dicabut pada tahun 1868. Seiring dengan itu, banyak penduduk Jepang yang tertarik melakukan emigrasi demi mencari penghidupan yang lebih damai, layak, dan sejahtera. Netsu merupakan istilah yang merujuk pada demam emigrasi yang melanda Jepang pada saat itu (Jones, 2005). Dalam situasi ini, Amerika Serikat tampak menjanjikan bagi para imigran Jepang.

Di masa-masa awal kontak, Jepang bukanlah partner strategis bagi Amerika secara khusus atau negara-negara Barat lain secara umum. Hal ini terlihat paling tidak jika dibandingkan dengan kepopuleran Cina bagi bangsa Barat pada abad ke 18-19. Misi diplomatik Amerika dan Jepang mulai dijalin oleh Komodor Matthew C.Perry pada tahun 1853. Diantara fokus hubungan diplomatik tersebut adalah pembukaan area perburuan ikan paus dan sejumlah kecil misi dagang (Ueda, 2020). Pada tahun 1854 ditandatangani piagam bilateral (bilateral treaty) antara Amerika dan Jepang. Keberhasilan pembukaan hubungan bilateral Amerika-Jepang tersebut dianggap atas jasa kebijakan Perry's gunboat diplomacy yaitu penggunaan atau gertakan secara militer untuk mendorong terbukanya hubungan diplomatik (National Museum of American Diplomacy, 2018).

Pasca bilateral treaty hubungan Amerika Jepang terus terkait seiring menggeliatnya gelombang imigrasi bangsa Jepang ke Amerika. Pemberlakukan Chinese Exclusion Act 1882 diawal seolah membuat peta serapan tenaga kerja Cina di Amerika berpindah ke bangsa Jepang. Meski begitu, alih-alih meminimalisir sentimen rasial dengan membuka kesempatan bagi bangsa Jepang atau Asia non-Cina, ternyata perlakukan rasis dan diskriminatif tetap saja menyasar pekerja 
Jepang. Dalam hal ini terjadi generalisasi atau bahkan sikap rasis dan diskriminatif secara umum pada imigran Asia. Demi keselamatan warganya, pemerintah Jepang melalui Gentlemen's Agreement 1907 kemudian menutup kesempatan emigrasi ke Amerika Serikat. Demikian pula, pada 1924 melalui the US Immigration Act Amerika Serikat melarang imigrasi bangsa Jepang atas dasar tidak dapat dipenuhinya syarat naturalisasi (Ueda, 2020).

Telah banyak tulisan mengenai fenomena setimen anti-Jepang di Amerika. Dua diantaranya, misalnya, membatasi konteks munculnya sentimen-sentimen yang dimaksud dengan cakupan kurun waktu. Yang pertama adalah studi yang dilakukan oleh Tamayo (2020) dengan artikel berjudul "The Perilous Borderlands: The Role of Anti-Japanese Hysteria in American Efforts to Annex Baja California, 1900-1942”. Artikel tersebut membahas tentang sikap-sikap anti Jepang kurun 1900-1942, khususnya di California dan politik tersembunyi yang mengiringinya. Termasuk juga upaya aneksasi wilayahwilayah strategis. Yang kedua dilakukan oleh Wallace (2021) melalui presentasinya berjudul "Economic Pressures and Anti-Japanese Sentiment in the US (1970-1993)". Dalam presentasinya, Wallace memotret isu-isu antiJepang yang muncul pada kurun 1970-1993, sebab-sebab, dan dampak sosialnya. Kedua kajian tersebut menggambarkan sebab-sebab, bentuk-bentuk, proses dan dampak munculnya sentimen anti-Jepang di Amerika dalam periode tertentu. Dalam hal ini, kedua pembahasan tidak langsung menghubungkan konteks munculnya fenomena serupa dengan isu Covid-19 dan sikap anti-Asian yang merebak setidaknya satu setengah tahun berjalan ini (sejak 2020).

Artikel ini berupaya memotret sejarah dinamika sosial yang dialami oleh imigran Jepang di Amerika Serikat dan merefleksikannya dengan kebencian anti-
Asian yang terjadi seiring merebaknya isu dan kecurigaan penyebaran Covid-19 yang dialamatkan kepada pendatang maupun warga keturunan Asia (umumnya oriental). Dinamika yang dimaksud mencakup bentuk-bentuk, sebab, dan pemicu sentimen terhadap imigran dan warga keturunan Jepang di Amerika dulu dan kini. Untuk mendapatkan hasil riset yang terfokus digunakan beberapa pertanyaan riset yaitu: (1) apa saja bentuk-bentuk sentimen yang menarget para imigran Jepang dulu dan kini, (2) mengapa sentimen muncul, dan (3) bagaimana, rasisme, diskriminasi, dan xenophobia dapat saling terhubung dalam konteks sentimen anti-Asian. Dengan mengelaborasi jawaban-jawaban atas pertanyaan tersebut akan didapatkan informasi dan sejarah yang selanjutnya akan digunakan untuk merefleksikan sikap anti-Asian yang merebak belakangan ini di Amerika Serikat.

\section{Metode}

Informasi dan teori pada artikel ini didapatkan dengan metode pengambilan data studi pustaka (library research). Dalam riset yang dilakukan, penulis terlebih dahulu melakukan listing judul ataupun topik artikel, jurnal, buku, surat kabar, dan sumber lain yang memiliki relevansi dengan judul artikel jurnal. Dalam hal ini dipilih judul dan topik artikel yang berkaitan dengan sejarah imigrasi bangsa Jepang di Amerika, masalah-masalah sosial yang mengiringinya, serta perkembangan kehidupan para imigran Jepang itu sendiri. Tahap selanjutnya mengharuskan adanya proses pembacaan intensif dan pemilahan data-data yang relevan dengan tujuan penulisan artikel. Setelah dilakukan tahap tersebut maka data yang terinventarisasi akan diolah oleh penulis dengan menggunakan pendekatan tertentu yang relevan. Dalam hal ini digunakan pendekatan sejarah, sosial, dan budaya untuk mengolah data-data yang telah dipilah. Pada akhirnya, kesemua data berikut proses pendekatan dan pengolahan akan 
menghasilkan sintesis yang tertuang dalam hasil maupun kesimpulan artikel jurnal ini.

\section{Hasil dan Pembahasan}

\subsection{Sentimen dan Isu pada Masa Awal}

Terdapat beberapa klasifikasi imigran ataupun keturunan Jepang di Amerika Serikat yaitu (1) Issei (generasi imigran yang paling awal dan lahir di Jepang), (2) Nisei (keturunan generasi imigran awal dan lahir di Amerika Serikat), (3) Sansei (keturunan Nisei), (4) Yonsei (keturunan Sansei dan merupakan generasi kelima), dan (5) Shin Issei (para pendatang baru; umumnya para pebisnis Jepang beserta keluarga yang dibawanya ke Amerika Serikat) (Hikoyeda \& KG Tanabe, 2010). Klasifikasi ini diperlukan guna melihat konteks waktu dan sosial ketika sentimen-sentimen anti-Jepang terjadi.

Di masa-masa awal imigrasi, Hawaii merupakan tempat yang aman dan akomodatif bagi para imigran Jepang (Library of Congress). Para imigran yang bekerja sebagai buruh kontrak di perkebunan tebu di Hawaii hidup normal dan mampu menyesuaikan diri dengan lingkungan (Thorndike, 2015). Dengan populasi yang semakin membesar kelompok imigran Jepang ini semakin terlihat dalam konteks interaksi sosial masyarakat Amerika. Hal ini tampak dari adanya komunitaskomunitas berbasis etnis Jepang pada masa itu.

Antara tahun 1885 dan 1895 diperkirakan terdapat 25.000 buruh kontrak Jepang di Hawaii (Report of the Commission on War Time Relocation and Internment of Civilians, 1997). Sesudahnya, banyak yang masuk ke daratan utama Amerika Serikat terutama di area Pesisir Barat atau wilayah California. Dominasi imigran Cina perlahan mulai diwarnai oleh kelompok imigran Jepang. Pengaruh Chinese Exclusion Act 1882 ikut andil mengubah peta populasi imigran pekerja berdasar etnis di Amerika. Meski begitu, situasi ini tidak mengubah kondisi sosial para imigran pekerja Jepang yang mana perekrutan buruh lebih didasarkan pada murahnya upah (Thorndike, 2015). Pada saat itu, mayoritas imigran Jepang ini berada dalam strata sosial bawah. Lebih lanjut, mayoritas imigran pekerja Jepang awal dulunya memang berlatarbelakang petani dan memiliki sedikit pengalaman kerja pada bidang lain. Meski begitu, banyak juga imigran Jepang berprofesi sebagai petani sukses yang memiliki, mengolah tanah, dan mengembangkan usaha pertaniannya sendiri karena bekal keterampilan bertani yang baik (Report of the Commission on War Time Relocation and Internment of Civilians, 1997).

Sentimen anti Jepang merebak di Amerika Serikat khususnya di Pesisir Barat (West Coast) seiring tumbuhnya populasi para imigran golongan Issei dan Nisei. Serangan Jepang ke Pearl Harbor nantinya juga menjadi pemicu semakin memburuknya setimensetimen anti Jepang. Pada tahun 1922, Mahkamah Agung Amerika Serikat memaknai Naturalization Act of 1790 dengan nada sentimen dan rasis dimana terdapat larangan naturalisasi untuk semua pendatang oriental / Asia Timur, termasuk Jepang (Report of the Commission on War Time Relocation and Internment of Civilians, 1997). Hilangnya hak naturalisasi ini berimbas pada posisi tawar para imigran Jepang di Amerika Serikat kala itu. Sebelumnya, pada tahun 1913, juga terdapat Alien Land Laws yang melarang nonkebangsaan Amerika memiliki ataupun menjual tanah (Japanese American National Museum, 2019). Ini akhirnya membuat para imigran Jepang golongan Issei mengalihnamakan kepemilikan tanah kepada keturunan Eropa-Amerika atau kepada anakanak mereka yang lahir di Amerika (Nissei) (Library of Conggres).

Pasca peristiwa Pearl Harbor pada 9 Desember 1941 semakin banyak imigran dan warga keturunan Jepang di Amerika menjadi sasaran kecurigaan dan kekerasan anti-Jepang 
(Ichise, 2005). Sebagian sikap ini bahkan kemudian dilegalisasi dalam undang-undang. Diantaranya yaitu Excutive Order 9066 yang ditandatangani oleh President Roosevelt pada 19 Februari 1942. Dalam kebijakan yang tertuang didalamnya, Departemen Pertahanan (Urusan Perang) Amerika akan mengusir dan mengasingkan siapapun di Pesisir Barat (the West Coast) yang merupakan keturunan Jepang baik yang berkebangsaan Amerika maupun tidak dan melarang mereka untuk mendapatkan alih status kebangsaan Amerika (Report of the Commission on War Time Relocation and Internment of Civilians, 1997). Menurut catatan sumber sebelumnya, imbas peristiwa ini 120.000 penduduk yang terdiri atas imigran dan warga keturunan Jepang diasingkan ke kamp relokasi. Selanjutnya hal ini berdampak pada kehidupan psikologis dan ekonomi masing-masing (Report of the Commission on War Time Relocation and Internment of Civilians, 1997).

Populasi imigran Asia yang berasal dari Jepang memang bukanlah yang terbesar di Amerika. Dalam statistik, porsi imigran Jepang jauh dibawah Cina. Meski begitu bukan berarti juga populasi imigran Jepang tidak bertumbuh. Terdapat propaganda anti Jepang di kurun awal abad 20 sementara jumlah komunitas ini mulai bertumbuh. Kehadiran imigran Jepang dianggap sebagai ancaman bagi para pekerja dan perempuan Amerika. Mereka dicurigai akan menggerogoti kedaulatan masyarakat Amerika. Sentimen semacam ini umum diekspresikan melalui media cetak berupa selebaran ataupun media cetak yang semacam. Ketua Federasi Buruh Amerika (American Federation of Labor) pada masa itu, Samuel Gompers, mencela dan melarang keanggotaan untuk imigran Jepang. Bahkan para walikota dan legislator meneriakan pemberlakukan Japanese Exclusion Act (Library of Congress). Pada 7 Mei 1900, dalam skala kolektif, kelompok-kelompok buruh lokal berdemonstrasi menyerukan sikap anti Jepang
(Report of the Commission on War Time Relocation and Internment of Civilians, 1997).

Isu anti Jepang yang awalnya lebih menyorot masalah kesempatan kerja kemudian merembet ke masalah kedaulatan politik. Ueda (2020) menyebut kemenangan Jepang pada serangan terhadap Rusia di tahun 1904-1905 membuat Jepang tampak ekspansif di mata dunia. Hal ini pada gilirannya menambah kekhawatiran masyarakat Amerika. Sebagian menganggap bahwa imigran Jepang adalah kepanjangan tangan Kekaisaran yang akan mengancam kedaulatan bangsa (Report of the Commission on War Time Relocation and Internment of Civilians, 1997). Memang, pada masa itu sebagian generasi Nisei dikirim oleh orang tuannya ke Jepang untuk mendapatkan pendidikan disana. Kelompok ini kemudian dicurigai sebagai agen ekonomi dan politik Jepang yang memiliki ambisi di Amerika (Jin, 2016).

Sentimen anti Jepang mewujud dalam berbagai ekspresi verbal maupun diskriminasi. Campney (2019) menyatakan bahwa di South Texas, kurun tahun 1907, para imigran Jepang yang masuk ke Amerika melalui Mexico ditolak oleh hotel-hotel tempat mereka akan menginap. Merujuk pada sumber yang sama, selanjutnya, para imigran ini telantar di jalanan dan sebagian ditahan oleh otoritas setempat (Campney 2019).

Sebagian masyarakat kulit putih Amerika menawarkan pekerjaan untuk para imigran Jepang. Sayangnya pekerjaan ini tampak diskriminatif dimana upah yang akan diterima hanya sekitar \$2 setiap minggunya dengan akomodasi tempat tidur di kandang kuda (Campney, 2019). South Texas sendiri pada masa itu sebenarnya adalah wilayah multirasial. Meski begitu, kelompok white supremacist cukup mendominasi disana. Sebagian masyarakat Amerika memandang imigran Jepang penuh kecurigaan sebagai 
kelompok cerdas dan licik. Sikap tekun yang mencirikan para imigran Jepang sampai batas tertentu justru menjadi ancaman dan kekhawatiran bagi sebagian masyarakat Amerika (Campney, 2019).

Sentimen anti Jepang di Amerika juga mewujud secara kolektif dan terlembaga. Pada tahun 1905 misalnya berdiri sebuah perkumpulan organisasi bernama the Asiatic Exclusion League (AEL). Organisasi ini getol menyuarakan pencegahan integrasi imigran Jepang dengan masyarakat Amerika secara luas (Thorndike, 2015). Perkumpulan ini pada gilirannya mampu mendesak dan mempengaruhi kebijakan pendidikan di San Fransisco dimana para siswa Jepang harus bersekolah secara terpisah dengan warga kulit putih. Sebelum organisasi ini, pada tahun 1894 pernah berdiri Immigration Restriction League (IRL) yang menyasar bukan hanya imigran Jepang, tetapi juga Korea dan Cina. Diinisiasi oleh para pebisnis dari East Coast, organisasi ini mengkampanyekan kesempatan imigrasi bagi orang-orang Eropa dan di sisi lain merendahkan potensi imigran Asia (Thorndike, 2015). Organisasi serupa seperti Anti-Japanese League di Seattle dan Washington juga turut andil menyuarakan sentimen anti Jepang pad a masanya.

\subsection{Sentimen dan Isu Saat Ini}

Tersiar oleh berbagai media, sentimen rasial tengah mengemuka di Amerika Serikat. Frasa anti-Asian menjadi topik pemberitaan. Frasa tersebut merujuk pada sikap kebencian terhadap imigran maupun warga keturunan Asia utamanya Oriental (Asia Timur). Kebencian ini mewujud dalam ekspresi verbal dan bahkan tidak jarang fisik. Mengutip CNBC (2021), "AAPI (Asian American Pacific Islander) mencatat sekitar 500 insiden antiAsia dalam dua bulan pertama tahun 2021 di Amerika. Setahun terakhir terdapat 3.795 keluhan dimana $68 \%$ darinya merupakan pelecehan verbal dan $11 \%$ adalah serangan fisik".

Belum lama pada 16 Maret 2021, delapan orang yang mana enam darinya merupakan keturunan Asia, tewas dalam penembakan di sebuah panti pijat di Atlanta (the New York Times, 2021). Motif terus didalami. Belakangan terdapat informasi bahwa motif penembakan berlatar masalah kecanduan seks. Dilansir The News Tribune (2021) seorang, warga Amerika keturunan Jepang, Nasu Noriko, mengalami cedera patah tulang pada wajah dan kerusakan gigi setelah dirinya dilempar batu di kawasan distrik Chinatown pada Februari 2021. Di kesempatan lain, seorang atlet warga Amerika keturunan Jepang diteriaki oleh sekelompok pria dengan makian "pecundang!" dan "pulang saja! (ke negaramu)" (Kyodo News, 2021). Peristiwa serupa juga terjadi pada seorang pria keturunan Jepang di sebuah lokasi parkir dimana ia dikejar oleh seorang pria kulit putih yang menuduhnya menyebarkan Covid-19 (Ho, 2020).

Peristiwa demi peristiwa terjadi dan akhirnya menjadi perhatian publik secara luas di Amerika. Terjadi berbagai gelombang protes menuntut ad anya perlindungan pada kelompok Asian-American dan penindakan hukum pada pengusung sikap anti-Asia.

Sentimen anti-Asian pada kurun waktu 2020-2021 ini diduga salah satunya dipicu oleh pernyataan rasis mantan Presiden Trump mengenai virus Covid-19. Trump mengasosiasikan Covid-19 sebagai China Virus, Wuhan Virus, atau dalam kesempatan lain Kung Flu (ABC News, 2021). Selama pendemi, kebencian anti-Asian meningkat tinggi. Ini seolah mirip dengan apa yang dialami oleh kaum Muslim di Amerika dan di dunia pada umumnya pasca terjadinya serangan teroris 11 September 2001 (The Washington Post, 2021). Mereka yang sama 
sekali tidak terkait tetap saja menjadi sasaran kebencian dan kekerasan verbal serta fisik karena kecurigaan dan kebencian yang telanjur menguat. Dalam sebuah survey oleh Pew Research Center (2021), setidaknya tiga dari sepuluh warga Amerika-Asia mendapat hinaan dan gurauan bernada rasis selama pandemi Covid-19.

Sikap kebencian kepada warga keturunan Asia tidak hanya diusung oleh masyarakat biasa. Banyak diantara pejabat di Amerika turut andil mengobarkan kebencian semacam. Sebagaimana diberitakan oleh kantor berita NHK, bahkan ditengah pengusutan kasus penembakan Atlanta seorang Sheriff dinas terkait (Cherokee County Police Department) dicopot setelah kedapatan mengusung rasisme melalui akun media sosialnya (NHK, 2021). Pejabat publik memiliki peran signifikan dalam mempengaruhi opini yang beredar di masyarakat. Dalam beberapa kasus anti-Asian di Amerika terdapat fenomena dimana pejabat publik ikut mengobarkan kebencian melalui ujaran-ujaran di media sosial.

Menyikapi kebencian anti-Asian yang belakangan merebak, Senat Amerika mulai menanggapi rancangan undang-undang anti kebencian terhadap kelompok keturunan Asia di Amerika. Dilansir dari ABC News pada 20 April 2021, rancangan undang-undang yang dimaksud mendapat sambutan positif dari mayoritas anggota Senat. Dalam hal ini, terdapat upaya institusional untuk meredam munculnya kebencian-kebencian serupa atau bahkan yang lebih buruk. Figur Senator Amerika keturunan Jepang-Amerika, Mazie Hirono, turut membidani gagasan undangundang anti kebencian tersebut (Hawaii News Now, 2021). Ia bersama anggota Senat dari partai Demokrat, Senator Tammy Duckworth, bekerjasama untuk menggoalkan undangundang yang dimaksud.

\subsection{Rasisme, Diskriminasi, dan Xenophobia sebagai Masalah Berulang yang Saling Terkait}

Fenomena kebencian terhadap etnis Asia di Amerika tampak seperti masalah yang berulang. Dengan mengambil contoh-contoh kasus kebencian yang menyasar imigran Jepang maupun warga keturunan Asia sejak masa awal kedatangan hingga dewasa ini nampaknya terdapat gejala yang mirip antara kedua konteks tersebut. Gejala yang dimaksud mengarah pada xenophobia. Berikut beberapa definisi xenophobia sebagaimana dikutip dari Crush dan Ramachandran (5:2009),

"Berezin defines xenophobia as the fear of difference embodied in persons or groups. For Nyamnjoh, xenophobia is the intense dislike, hatred or fear of others. It has been characterized as an attitudinal orientation of hostility against nonnatives in a given population. And, it has been seen as hostility towards strangers and all that is foreign. Another definition views xenophobia as attitudes, prejudices, and behaviour that reject, exclude and often vilify persons based on the perception that they are outsiders or foreigners to the community, society or national identity".

Mengacu pada beberapa definisi xenophobia yang dipaparkan, kesemuanya menunjukan adanya kata kunci yang sama yaitu kebencian dan penolakan terhadap kelompok "lain". Kebencian yang dimaksud terdapat kaitan dengan konsep "asing" dan "tidak asing" ataupun "penduduk asli" dan "pendatang" . Perbedaan identitas yang umumnya mengacu pada asal komunitas, masyarakat, ataupun kebangsaan, dengan begitu, dapat menjadi pemicu fenomena xenophobia.

Kebencian bernuansa xenophobic yang menyasar warga keturunan Asia di Amerika semakin tampak eksplisit dalam ekspresi- 
ekspresi verbal seperti "go back to your country!" atau "go back to China!" yang dialamatkan kepada sasaran kebencian. Dilaporkan oleh Sam Cabral melalui surat kabar elektronik BBC (2021), selama 2020 (terhitung dari Maret-Desember) terdapat 2.808 insiden yang menyasar imigran maupun warga keturunan Asia di Amerika. Secara detail, $21 \%$ dari insiden tersebut merupakan perilaku penghindaran dan $8 \%$ berwujud dalam penolakan pelayanan dan diskriminasi di tempat kerja.

Informasi menyesatkan mengenai masalah Covid-19 menjadi salah satu pemicu sentimen anti-Asian di kurun waktu dua tahun ini. Menengok kebelakang, sentimen anti-Asian yang menyasar imigran dan warga keturunan Cina maupun Jepang banyak dipicu oleh isu seputar lapangan kerja dan kekhawatiran ekspansi politik. Di sisi lain, terdapat juga kesamaan-kesamaan dalam hal target kebencian yang disasar, adanya informasiinformasi yang menyesatkan, adanya andil pejabat publik dalam isu-isu kebencian, dan keterlibatan lembaga negara dalam menentukan kebijakan atas masalah terkait.

Dalam konteks kebencian anti-Asian di Amerika Serikat, xenophobia sendiri bisa jadi adalah tampak permukaan. Isu-isu sosialpsikologis lain turut mengiringi fenomena ini. Hal ini, misalnya, tampak jika masalah xenophobia disandingkan dengan konsep rasisme. Dalam konvensi internasional (Bagian 1, Artikel 1) rasisme didefinisikan sebagai,

"any distinction, exclusion, restriction
or preference based on race, colour,
descent or national or ethnic origin
which has the purpose or effect of
nullifying or impairing the recognition,
enjoyment or exercise, on a equal
footing, of human rights and
fundamental freedoms in the political,
economic, social, cultural or any other

"any distinction, exclusion, restriction or preference based on race, colour, descent or national or ethnic origin which has the purpose or effect of nullifying or impairing the recognition, enjoyment or exercise, on a equal footing, of human rights and economic, social, cultural or any other field of public life" (International Convention on the Elimination of All Forms of Racial Discrimination, 1969).

Sebagian besar penanda rasial merupakan tampilan fisik berupa warna kulit, rambut, bentuk mata, hidung, dan lain sebagainya. Para imigran maupun warga keturunan Asia menjadi target kebencian dengan terlebih dahulu diidentifikasi oleh pelaku melalui tampilan fisiknya. Pola ini dapat terus berulang dan bukan tidak mungkin menjelma menjadi masalah rasisme. Pada kesempatan lain, rasisme akan menjadi akar masalah-masalah diskriminasi. Dengan begitu, xenophobia justru akan menjadi gejala saja. Sementara rasisme adalah inti permasalahan.

Melihat bahwa rasisme bisa menjadi akar permasalahan xenophobia, pada gilirannya masalah diskriminasi bukan tidak mungkin akan mengikutinya. Dalam banyak kasus, rasisme akan memunculkan kecenderungan perilaku diskriminatif. Menengok sejarah sentimen terhadap imigran Jepang di Amerika, banyak peran publik dan akses kepemilikan properti seperti tanah garapan imigran Jepang yang akhirnya ditangguhkan oleh undangundang yang berlaku pada saat itu. Bahkan pada masanya juga didapati pengusiran dan relokasi yang dijustifikasi oleh peraturan resmi dari otoritas.

\section{Kesimpulan}

Undang-undang Chinese Exclusion Act 1882 yang didalamnya memuat larangan imigrasi dan naturalisasi bagi imigran Cina berdampak pada munculnya rasisme dan diskriminasi terhadap imigran dan warga keturunan Cina pada masanya. Tidak hanya imigran dan warga keturunan Cina saja, seiring dengan itu ternyata para imigran pekerja dan warga keturunan Jepang juga menjadi sasaran rasisme dan diskriminasi. Disini seolah terdapat generalisasi identitas etnis (dengan identifikasi utama oriental) yang sebelumnya didominasi 
oleh isu anti-Cina kemudian berkembang menjadi anti-Asian ataupun anti-Jepang. Kemenangan Jepang pada perang dengan Russia 1904-05 dan serangannya ke Pearl Harbor menguatkan kecurigaan dan sentimen terhadap imigran dan warga keturunan Jepang sebagai agen politik Kekaisaran.

Imigran dan warga keturunan Jepang mendapatkan cap negatif sebagai penyusup politik yang nantinya akan menggerogoti Amerika. Selanjutnya, terdapat banyak peristiwa pengusiran, ujaran kebencian melalui selebaran, dan diskriminasi dalam skala individual maupun yang diorganisasi secara kelompok. Aksi bernuansa rasis, diskriminatif, dan xenophobic ini pada gilirannya juga mendapat justifikasi otoritas di Amerika. Ini misalnya tampak dari adanya kebijakan Excutive Order 9066 yang memaksa warga Jepang di West Coast terusir dan tinggal di pengasingan. Selain itu, kebijakan serupa juga ditemui dari adanya undang-undang pelarangan kepemilikan tanah dan hilangnya kesempatan naturalisasi seperti tertuang di Alien Land Laws.

Saat ini, merebaknya Covid-19 seolah sedang memunculkan luka lama yang dialami imigran dan warga keturunan Asia, termasuk Jepang, di Amerika Serikat. Beragam bentuk rasisme, diskriminasi, dan xenophobia menyasar kelompok dan individu keturunan Asia. Berbeda dengan pemicu kejadian serupa di masa lalu, kebencian yang menyasar kelompok keturunan Asia kini dikobarkan melalui isu penyebaran virus Covid-19. Terdapat tokohtokoh berpengaruh di kalangan masyarakat Amerika menggunakan frasa "China Virus" ataupun "Wuhan Virus" untuk mengacu pada Covid-19. Pada gilirannya, hal tersebut memicu kecurigaan dan sentimen publik dalam bentuk verbal maupun serangan fisik terhadap imigran dan warga keturunan. Banyak survei mendapati adanya peningkatan tajam dalam hal kebencian anti-Asian pada kurun pandemi Covid-19.

Meski pemicunya berbeda, terdapat kesamaan atas munculnya sikap anti-Asian dulu dan kini. Diantara kesamaan fenomena yang dimaksud adalah adanya prasangka-prasangka rasial yang akhirnya memunculkan kecurigaan, adanya peran otoritas di dalam merumuskan kebijakan publik atas isu terkait, serta adanya andil tokoh-tokoh publik di dalam mengobarkan kebencian dan kecurigaan. Media turut andil atas tersebarnya ekspresiekspresi kebencian terhadap warga keturunan Asia. Sementara pada masa lalu digunakan berbagai selebaran cetak, pada saat ini media sosial memiliki peran siginfikan dalam mempengaruhi opini publik atas isu anti-Asian.

\section{Sumber Referensi}

Batalova, J. B. M. H. A. J. (2021, March 10). Immigrants from Asia in the United States. Migrationpolicy.Org. https://www.migrationpolicy.org/articl e/immigrants-asia-united-states-2020

BBC News. (2021, April 23). Covid "hate crimes" against Asian Americans on rise.

https://www.bbc.com/news/world-uscanada-56218684

Beale, A. (2021, March 30). Anti-Asian hate crimes surge across the US. NHK WORLD. https://www3.nhk.or.jp/nhkworld/en/n ews/backstories/1564/

Brockell, G. (2021, March 18). The long, ugly 
history of anti-Asian racism and violence in the U.S. Washington Post. https://www.washingtonpost.com/histo ry/2021/03/18/history-anti-asianviolence-racism/

Campney, Brent M. S. "Anti-Japanese Sentiment, International Diplomacy, and the Texas Alien Land Law of 1921." Journal of Southern History, vol. 85 no. 4,2019 , p. 841-878. Project MUSE, doi:10.1353/soh.2019.0245.

Crush, J. \& Ramachandran, S. (2009). Xenophobia, International Migration and Human Development (rep., 1104). New York: United Nations Development Programme. Human Development Reports, Research Paper 2009/47.

Commission on Wartime Relocation and Internment of Civilians, \& Kashima, T. (1997). Personal Justice Denied: Report of the Commission on Wartime Relocation and Internment of Civilians. University of Washington Press.

Edmondson, C. (2021, April 22). Senate Advances Anti-Asian-American Hate Crimes Bill. The New York Times. https://www.nytimes.com/2021/04/14/ us/senate-anti-asian-american-hatecrimes.html

Evans, M. D. (2019). Blackstone's International Law Documents (Blackstone's Statute) (14th ed.). Oxford Univ Pr.

Education Resources | Japanese American National Museum. (2019). Japanese American National Museum. https://www.janm.org/education/resou $\underline{\text { rces }}$
Hawaii: Life in a Plantation Society | Japanese | Immigration and Relocation in U.S. History | Classroom Materials at the Library of Congress | Library of Congress. (n.d.). The Library of Congress.

https://www.loc.gov/classroommaterials/immigration/japanese/hawaii -life-in-a-plantation-society/

Hikoyeda, N, DrPH, MPH \& Tanabe, M, MD: Health and health care of Japanese American Older Adults https://geriatrics.stanford.edu/et hnomed/japanese.html/. In Periyakoil VS, eds. eCampus-Geriatrics, Stanford CA, 2010.

Japanese immigrants. (2015). Immigration to the United States. https://immigrationtounited states.org/6 63-japanese-immigrants.html

Japanese in the U.S. Fact Sheet. (2020, May 30). Pew Research Center's Social \& Demographic Trends Project. https://www.pewresearch.org/socialtrends/fact-sheet/asian-americansjapanese-in-the-u-s/

Jennifer Ho (2021) Anti-Asian racism, Black Lives Matter, and COVID-19, Japan Forum, 33:1, 148-159, DOI: 10.1080/09555803.2020.1821749

Jones, L. (2005, May). Japanese American immigration and assimilation. ScholarWorks. https://scholarworks.calstate.edu/conce $\underline{\mathrm{rn} / \mathrm{theses} / 0 \mathrm{c} 483 \mathrm{~m} 65 \mathrm{~b}}$

Kyodo News, K. N. (2021, April 10). Japanese American Olympic athlete targeted in anti-Asian rant. https://english.kyod onew s.net/news/20 21/04/12cf43d4a496-japanese- 
american-olympic-athlete-targeted-inanti-asian-rant.html

Michael Jin. (2016). Americans in the Pacific: Rethinking Race, Gender, Citizenship, and Diaspora at the Crossroads of Asian and Asian American Studies. Critical Ethnic Studies, 2(1), 128. https://doi.org/10.5749/jcritethnstud.2. $\underline{1.0128}$

Pecorin, A. (2021, April 19). Hirono: AntiAsian hate bill chance for Senate to "take a stand." ABC News. https://abcnews.go.com/Politics/hirono -anti-asian-hate-bill-chance-senatestand/story?id=77163413

Racism. (2018, September 12). National Museum of American History. https://americanhistory.si.edu/rightingwrong-japanese-americans-and-world$\underline{\text { war-iii/racism }}$

Ruiz, N. G., Edwards, K., \& Lopez, M. H. (2021, April 21). One-third of Asian Americans fear threats, physical attacks and most say violence against them is rising. Pew Research Center. https://www.pewresearch.org/facttank/2021/04/21/one-third-of-asianamericans-fear-threats-physicalattacks-and-most-say-violenceagainst-them-is-rising/

Sorongan, T. P. (2021, March 24). Bukan Cuma Amerika, Anti-Asia Merebak di Banyak Negara. news. https://www.cnbcind onesia.com/news/ 20210324132124-4-232506/bukancuma-amerika-anti-asia-merebak-dibanyak-negara

Staff, H. (2021, April 22). Anti-Asian hate crimes bill, introduced by Hirono, passes Senate with bipartisan support. https://www.hawaiinew snow.com. https://www.hawaiinew snow.com/202 1/04/22/senate-poised-pass-anti-asianhate-crimes-bill-introduced-by-senhirono/

Tamayo, D. (2020). The Perilous Borderlands. California History, 97(2), 59-87. https://doi.org/10.1525/ch.2020.97.2.5 $\underline{9}$

The History of Japanese Immigration to the United States. (2005). KCC AlternaTV

News.

http://www2.hawaii.edu/\%7Esford/alte rnatv/s05/articles/laura_history.html

The News Tribune. (2021, March 22).

Chinatown attack on teacher not hate crime - yet, Washington officials say. Here's why. https://www .thenewstribune.com/news /state/washington/article250132974.ht $\underline{\mathrm{ml}}$

Thorndike, J. L. (2015). Japanese immigrants. Immigration to the United States.

https://immigrationtounited states.org/6 63-japanese-immigrants.html.

Ueda. (2020, June 27). A Brief, Cautionary, History of Japan-US Immigration. The Diplomat.

https://thediplomat.com/2020/06/abrief-cautionary-history-of-japan-usimmigration/

Wallace, D. (2021). Economic Pressures and Anti-Japanese Sentiment in the US (1970-1993). Murray State's Digital Commons.

https://digitalcommons.murraystate.ed u/scholarsweek/Spring2021/GlobalLan guages/4/ 